\title{
Key Legal Issues and Challenges in the Recovery of the Proceeds of Crime: Lessons from Nigeria
}

\author{
Abdullahi Y. Shehu ${ }^{1}$ \\ ${ }^{1}$ School of Arts and Social Sciences, National Open University of Nigeria, Lagos, Nigeria \\ Correspondence: Abdullahi Y. Shehu, School of Arts and Social Sciences, National Open University of Nigeria, \\ No. 24/26, Ahmadu Bello Way, VIctoria Island, Lagos, Nigeria. Tel: 234-806-566-0502. E-mail: \\ shehu2000@gmail.com
}

$\begin{aligned} & \text { Received: September 16, } 2014 \quad \text { Accepted: October 8, } 2014 \quad \text { Online Published: October 30, } 2014 \\ & \text { doi:10.5539/ilr.v3n1p186 }\end{aligned} \quad$ URL: http://dx.doi.org/10.5539/ilr.v3n1p186

\begin{abstract}
It is estimated that proceeds of corruption, also referred to as illicit enrichment, constitutes the main predicate for money laundering in Africa. It, therefore, remains the greatest obstacle to development. This paper presents the issue of illicit enrichment involving politically exposed persons and, drawing from the lessons of Nigeria in the recovery of such proceeds, discusses some international initiatives, as well as the legal framework for asset recovery in Nigeria. The main thrust of the paper is to discuss the key legal issues and challenges in the recovery of the proceeds of illicit enrichment and recommend steps to address those challenges.
\end{abstract}

\section{Introduction}

Corruption has undermined efforts to provide good governance and to effectively tackle social problems including the prevention and control of criminality. Corruption is prevalent, especially in the public sector ${ }^{1}$, virtually endemic and institutionalized, with the following most dominant variety of techniques for its perpetration:

1) Embezzlement, misappropriation, or other diversions of public property/funds by government officials;

2) Bribery of Government officials;

3) Inflation of contracts and over-invoicing for public works and procurement;

4) Abuse/ misuse of office for personal gains

5) Trading in "influence" to get things done or not done; and

6) Illegal transfer or taking of money abroad.

The sources of illicit finance are legion and it would not be possible to go into the details here. Suffice it to say that illicit finance is a manifestation of the prevalence of predicate crimes ${ }^{2}$. In a recent report by the Global Financial Integrity (GFI) entitled “Transnational Crime in The Developing World” (February 2011), three forms by which illicit money is generated in the developing world were identified ${ }^{3}$. These are:

1) bribery and theft by government officials,

2) criminal activity, and

3) commercial tax evasion.

The literature-based study carried out by GFI covered twelve criminal activities - illicit drugs, human trafficking, wildlife, counterfeiting, trade in human organs, small arms, diamonds and other gems, oil, timber, fish, art and cultural property, and gold. The findings revealed that these 12 categories of criminal activity generate global proceeds of some $\$ 650$ billion annually. Illicit drug trafficking has the highest proceeds, followed by counterfeiting.

\footnotetext{
${ }^{1}$ This does not mean the private sector is immune to corruption, but the focus of this paper is on public corruption.

${ }^{2}$ Namely, drugs, human and arms trafficking, corruption, fraud, tax evasion and money laundering, among others.

3 Jeremy Haken, Transnational Crime In The Developing World”, Global Financial Integrity, February 2011.
} 
In an earlier report ${ }^{4}$, GFI estimated that in 2006, developing countries lost between US\$858.6 billion and $\$ 1.06$ trillion in illicit financial flows, an increase of $18.2 \%$ over 5 years (2002-2006). It further asserted that Asia accounted for approximately 50\%; Europe - 17\%; MENA region and Western Hemisphere - 15\%; and Sub-Saharan Africa - 3\%. Far from assuming that percentage for Africa is relatively small, the report revealed that Africa lost about $\$ 854$ billion in illicit financial outflows from 1970-2008 -far in excess of its development aid and that the estimated total may be as high as $\$ 1.8$ trillion. The top five countries with the highest outflow were: Nigeria (89.5billion); Egypt (70.5billion); Algeria (25.7billion); Morocco (25 billion); and South Africa (24.9 billion). What does this represent? It means an increase of $11.9 \%$ per annum. Furthermore, the illicit financial flows are correlated to resource endowment (including the flows from oil producing countries like Angola and Gabon) and the prevalence of corruption. Most importantly, since these are outflows, it means that these illicit financial resources have been taken out of Africa, thus denying the citizens of a right to improved living conditions and over all development.

The GFI Report (2011) also found that the cross-border passage of criminal money is facilitated by the global shadow financial system comprising tax havens, secrecy jurisdictions, disguised corporations, anonymous trust accounts, fake foundations, trade mispricing, and other money laundering techniques. Considering, however, that the study did not include criminal activities such as credit card fraud, advance fee fraud, intellectual property, piracy, carjacking, and other forms of illicit and underground economic activity, a realistic estimate of the proceeds generated from crime can only be imagined.

According to the World Bank, annual cross-border flow of proceeds from criminal activity is estimated at between US\$1-1.6 trillion. Half of this amount is looted from developing and transition economies and \$20-40 billion of this flow originated from bribes to public officials in developing and transition countries. ${ }^{5}$

Corruption is a major impediment to the rule of law. Corruption is not only a predicate offence for money laundering, but also the biggest impediment to the implementation of counter measures against money laundering - thus, it produces and protects money laundering. The laundering of criminal proceeds necessarily involves concealing the source of illicitly acquired assets. Perpetrators of these crimes often launder the proceeds of their crimes by bank transfers of these funds to other jurisdictions. But other methods of laundering have also evolved $^{6}$. In most developing countries, including Nigeria, corrupt leaders and other Politically Exposed Persons (PEPs) have, over the years, been able to conceal massive amounts of stolen wealth in offshore financial centres around the world. Apart from proceeds of other organized crimes, Heads of State Governors and other politically exposed persons in collusion with top civil servants embezzle public funds. Corruption is not only restricted to the public sector; it also thrives in the private sector. However, the consequence of public corruption is of major concern because it drains resources that would have otherwise been ploughed into building basic infrastructure and other development projects. It is in apperant realization of the negative impact of corruption and its corrosive effects that the international community has responded accordingly by creating the necessary legal framework for the prevention of corruption and the recovery of proceeds of crime.

\section{International Response}

The international community and governments have developed various tools for recovering the proceeds of crime. However, in spite of domestic legislation, which allows confiscation and forfeiture of the proceeds of crime, globalisation and technological advancement have allowed perpetrators of crime to continue to launder the illicit proceeds of their crimes. The subject of asset recovery has become one of the major themes in discourses on development funding, due in part to the enormous amount of resources that are lost annually by developing countries to corruption. Over the last couple of decades, the legal and criminological approach to dealing with criminal activities like drug trafficking corruption, money laundering and terrorist financing have undergone a paradigm shift from the utilitarian and the traditional "just deserts" model of punishment to a "dispossession" model which aims at taking the profit out of crime. Recovering the proceeds of crime takes the profit out of the crime because it deprives perpetrators of their illicit gains. Asset forfeiture and asset recovery have thus, become some of the more innovative tools to combat economic and financial crimes. Illicitly obtained

\footnotetext{
${ }^{4}$ Global Financial Integrity (GFI) 'The Absorption of Illicit Financial Flows from Developing Countries: 2002-2006; Illicit Financial Flows from Developing Countries (With Update from Asia) - 2000-2009; and Illicit Financial Flows from Africa: Hidden resource for Development (2009)'.

${ }^{5}$ Stolen Assets Recovery Initiative: Challenges, Opportunities, and Action Plan

${ }^{6}$ For the many methods of money laundering and terrorist financing, see typologies of the FATF and other FATF Style Regional Bodies from the following link: www.fatf-gafi.org/typologiesreports/
} 
funds are usually invested abroad either because domestic currency or economy is unstable, to avoid detection or place the money outside the reach of a national governments jurisdiction. Until recently, financial institutions in financial centres were quite accepting and would accept stolen money without question. This has now changed relatively due to the anti-money laundering standards being enforced the world over.

In order to properly contxtualize the legal issues and challenges in the recovery of proceeds of crime therefore, we will now provide an overview of the United Nations initiatives as contained in the relevant conventions and discuss the lessons drawn from case studies from Nigeria's efforts at recovery the proceeds of crime and enforcing the rule of law.

\section{The UN International Initiatives}

The UN responded to the growing concerns of its member states on the proliferation of transnational criminal activities by strengthening institutional frameworks through a number of global agreements and initiatives. The 1988 United Nations Convention against the Illicit Traffic of Narcotic Drugs and Psychotropic Substances (the Vienna Convention) set the path for a new generation of legal instruments prescribing this "dispossession" model, by prescribing confiscation of crime proceeds. Article 5 of the Convention sets out confiscation measures but related to drug offences only. Article 7 provides for mutual legal assistance, while articles 8 and 10 make provisions for transfer of proceedings in criminal matters, as well as international cooperation. These provisions, though pertinent to the recovery of th proceeds of crime, are not sufficient for the recovery of the proceeds of illicit enrichment.

Likewise, the United Nations Convention against Transnational Organized Crime (TOC - the Palermo Convention), which covers "organized crime activities", including corruption, obstruction of justice and money laundering also advocate confiscation, thus, providing the legal framework for countries to develop the necessary domestic legal measures for asset recovery. The importance of this Convention was underscored by Kofi Annan (former Secretary General of UN) when he stated that "criminal groups have wasted no time in embracing today's globalized economy and the sophisticated technology that goes with it. But our efforts to combat them have remained up to now very fragmented and our weapons almost obsolete. The Palermo Convention gives us a new tool to address the scourge of crime as a global problem. With enhanced international cooperation, we can have a real impact on the ability of international criminals to operate successfully, and help citizens everywhere in their often struggle for safety and dignity in their homes and communities"?

Specifcally, Article 12, paragraph 7 of the TOC provides that 'States Parties may consider the possibility of requiring that an offender demonstrate the lawful origin of alleged proceeds of crime or other property liable to confiscation' to the extent consistent with domestic law and the nature of the proceedings. Art. 53 of the UNCAC Provides that Each State Party shall, in accordance with its domestic law:

(a) Take such measures as may be necessary to permit another State Party to initiate civil action in its courts to establish title to or ownership of property acquired through the commission of an offence established in accordance with this Convention;

(b) Take such measures as may be necessary to permit its courts to order those who have committed offences established in accordance with this Convention to pay compensation or damages to another State Party that has been harmed by such offences; and

(c) Take such measures as may be necessary to permit its courts or competent authorities, when having to decide on confiscation, to recognize another State Party's claim as a legitimate owner of property acquired through the commission of an offence established in accordance with this Convention.

The United Nations Convention against Corruption (UNCAC) is the ground breaking convention on asset recovery. Without going into detail, the Convention is divided into eight chapters dealing with specific issues of international law. There are four main pillars in the Convention: (1) prevention; (2) criminalization and law enforcement; (3) asset recovery; and (4) international cooperation. The UNCAC explicitly identifies asset recovery as its fundamental principle. It enjoins States Parties to establish comprehensive domestic regulatory and supervisory regimes to prevent money laundering. ${ }^{8}$ Countries that have ratified the UNCAC are required to criminalize the offence of bribery, ${ }^{9}$ embezzlement, misappropriation or other diversion of property by a public

\footnotetext{
${ }^{7}$ Remarks by Kofi Annan, UN Secretary-General at the signing of the UN 2000 Convention in Palermo on 12 December 2000.

8 Article 14.

9 Articles 15 and 16
} 
official, ${ }^{10}$ and laundering of the proceeds of crime; ${ }^{11}$ however, criminalization of illicit enrichment, is left to the discretion of the States ${ }^{12}$. Nevertheless, Article 21 of the UNCAC encourages States Parties to put in place measures that would criminalize illicit enrichment, which is defined as "a significant increase in the assets of a public official that he or she cannot reasonably explain in relation to his or her lawful income",l3. Applying the principles of Article 21 means that a significant increase in the assets of a public servant raises a prima facie presumption that the public official concerned benefited from illicit enrichment. This presumption can be rebutted by furnishing facts which reasonably explain the legal source of the assets. While several jurisdictions have successfully enacted and enforced illicit enrichment, others consider it inconsistent with their constitutions and fundamental principles of due process.

By far, the greatest innovation of the Convention is contained in chapter five. Asset recovery and the return of such assets to countries of origin is a fundamental principle of this Convention, and this chapter contains provisions such as prevention and detection of transfers of proceeds of crime; measures for direct recovery of property; mechanisms for recovery of property through international cooperation in confiscation; international cooperation for the purposes of confiscation; return and disposal of assets; the requirement for the establishment of financial intelligence unit; as well as bilateral and multilateral agreements and arrangements (Articles 51-59). Specifically, Article 51 states: 'The return of assets pursuant to this chapter is a fundamental principle of this Convention, and States Parties shall afford one another the widest measure of cooperation and assistance in this regard.' And on matters of direct recovery of property, the Convention provides (Article 53) that

Each State Party shall, in accordance with its domestic law:

(a) Take such measures as may be necessary to permit another State Party to initiate civil action in its courts to establish title to or ownership of property acquired through the commission of an offence established in accordance with this Convention;

(b) Take such measures as may be necessary to permit its courts to order those who have committed offences established in accordance with this Convention to pay compensation or damages to another State Party that has been harmed by such offences; and

(c) Take such measures as may be necessary to permit its courts or competent authorities, when having to decide on confiscation, to recognize another State Party's claim as a legitimate owner of property acquired through the commission of an offence established in accordance with this Convention.

Before discussing some lessons from Nigeria with regard to applying these legal instruments, it is also important to mention other related international efforts and initiatives which promote the recovery of proceeds of crime and corruption or illicit enrichment in particular - and these are the FATF Recommendations and the StAR Initiative of the World and the United office on Drugs and Crime (UNODC).

\section{The FATF Recommendations}

The Financial Action Task Force (FATF) ${ }^{14}$, is an inter-governmental body set up to develop and promote national and international policies to combat money laundering and terrorist financing. The FATF used elements drawn from the Vienna and Palermo conventions to set down a series of 40 Recommendations, which provide a complete set of counter-measures against money laundering and terrorist financing and proliferation of weapons

\footnotetext{
10 Article 17

${ }^{11}$ Article 23

${ }^{12}$ It is crucial to note that criminalization not only allows national authorities to detect, prosecute and repress the offence but also provides the legal basis for international cooperation among law enforcement agencies, judicial and administrative authorities.

${ }^{13}$ One of the contentious issues during the elaboration of the Convention was the issue of the burden of proof in the prosecution of accused persons for illicit enrichment (Article 25). Whereas some delegates proposed the introduction of the kind of legislation which places the burden on the accused as in ss.12A and 14 of the Hong Kong Prevention of Bribery Ordinance and s.10 of the HK Bill of Rights Ordinance (1991 as amended), as well as s.4 of the Singaporean Confiscation of Benefits Act. Others, however, expressed the strong reservation that such provisions were tantamount to the violation of the right of presumption of innocence of an accused person. It should be noted that such provision does not in any way relieve the state from discharging the general burden of proof that rests on the prosecution; what is reversed is evidentiary burden in respect of the proof of certain facts.

${ }^{14}$ The FATF was established by the (G7) as an inter-governmental body to develop and promote national and international policies to combat money laundering and terrorist financing; it monitors members' progress in implementing these principles according to their unique circumstances and constitutional frameworks.
} 
of mass destruction covering the law enforcement, the financial system and its regulation, and international co-operation. Recommendation 4 (confiscation and provisional measures) enjoins countries to adopt legislative measures, to enable their competent authorities to confiscate property laundered, proceeds from money laundering or predicate offences, or instrumentalities used in or intended for use in the commission of these offences. It also calls upon countries to consider adopting measures that allow proceeds and instrumentalities of crime to be confiscated without requiring criminal conviction (non-conviction based confiscation). Together, the UNCAC and the FATF 40 recommendations provide effective tools for combating money laundering and reforming a culture of corruption by establishing a robust framework for asset recovery. Jurisdictions are required to implement the international initiatives at the national level by putting in place appropriate legal and institutional frameworks, including for the monitoring of PEPs (Recommendation 12).

\section{The StAR Initiative}

The Stolen Asset Recovery Initiative (StAR) is a partnership between the World Bank Group and the United Nations Office on Drugs and Crime (UNODC) that supports international efforts to end safe havens for corrupt funds. StAR helps countries establish the legal tools and institutions required to recover the proceeds of corruption. According to StAR, an effective legal framework should include:

a) domestic criminal prosecution and confiscation, which may where necessary, be followed by an MLA request to enforce orders in foreign jurisdictions;

b) NCB confiscation, which may where necessary, be followed by an MLA request or other forms of international cooperation to enforce orders in foreign jurisdictions;

c) private civil actions, including formal insolvency process;

d) criminal prosecution and confiscation or NCB confiscation initiated by a foreign jurisdiction (requires jurisdiction over an offense and cooperation from the jurisdiction harmed by the corruption offenses); and administrative confiscation.

The availability of these avenues, either domestically or in a foreign jurisdiction, will depend on the laws and regulations in the jurisdictions involved in the investigation, as well as international or bilateral conventions and treaties ${ }^{15}$.

It means therefore that countries can seek the support and assistance of the StAR to develop technical capacity and recover proceeds of illicit enrichment.

\section{Lessons from Nigeria}

In jurisdictions where illicit enrichment is criminalised, after securing a conviction, criminal forfeiture will form part of the sentencing. In Nigeria, Section 7(1) (b) of the Economic and Financial Crimes Commission (EFCC) Act (2004) gives special powers to the Commission in this respect. It states that the "Commission has power to cause investigations to be conducted into the properties of any person if it appears to the Commission that the person's lifestyle and extent of the properties are not justified by his source of income". Although this provision does not go as far as to criminalise illicit enrichment, the Commission could, nonetheless, employ this section to conduct an investigation on virtually any persons that appear to be 'living beyond their means' particularly politically exposed persons. Thus, the power to initiate an investigation should not only be subject to financial information disseminated to the EFCC based on a suspicious transaction report by a financial institution or other reporting entities. Section 7 grants wide powers of investigation to the EFCC. These powers ought to be used proactively by the EFCC.

A key provision of the $\mathrm{UNCAC}^{16}$ is Article 31, which obligates States parties to take necessary measures to enable confiscation, including measures to enable the identification, tracing, freezing or seizure of such property. In instances where it may be impossible to institute criminal proceedings against the accused, such as when an accused absconds or cannot be prosecuted for reasons of immunity; Articles 53 and 54 make provision for civil remedies. Article 54 (1) (c) encourages States Parties to give consideration to measures that would allow confiscation of the proceeds of corruption without a conviction. Article 53 enjoins jurisdictions to permit another state to initiate civil action in its courts to establish title to or ownership of property acquired through the commission of an offence prescribed by the convention. Although the EFCC Act (2004) and the Money

\footnotetext{
${ }^{15}$ Asset Recovery Handbook: A Guide for Practitioners J. Brun Larissa, G. Clive, S. Kevin, M. Stephenson

${ }^{16}$ It should be noted that Nigeria was one of first set of countries to sign and ratify this convention and has gone ahead to domesticate it and created various structures, including the Independent Corrupt Practices and Other Related offences Commission (ICPC), as well as the EFCC.
} 
Laundering (Prohibition) Act (MPLA) (2011) make provisions for seizure and confiscation, there is, however, no provision under the Nigerian law for non-conviction based confiscation ${ }^{17}$.

The provisions of Article 53 and 54 will permit countries to be able to bring an action in civil forfeiture against the asset itself rather than the person, who then become a third party claimant. In such a case, the state has to show that the assets are proceeds of an unlawful activity. Given that the standard of prove in a civil action, which is based on a balance of probabilities, is less than that required for criminal proceedings, civil forfeiture therefore opens up new routes to follow and confiscate assets beyond the reach of the criminal law (Shehu, 2006: 27).

Some countries have enacted legislation allowing for confiscation of assets in the possession of a public official, which cannot be accounted for as having come from legitimate sources of pre-existing wealth or present legitimate income. ${ }^{18}$ A less drastic but similar policy is to impose an onus to establish lawful origin or to create a reasonable doubt as to illicit origin, an approach taken by the UN Convention against Transnational Organized Crime and more specifically the Corruption Convention. In policy terms, it is argued that it is the official who is in the best position to account for the assets, but in legal terms the same concerns exist as for the presumption of criminal guilt. To the extent that confiscation of assets by the state is considered a criminal penalty, the concerns about infringement of legal rights and the need for appropriate procedural safeguards must be taken into account. Where adequate safeguards are in place, however, a reversal of onus or partial reversal of onus is an effective measure. The TOC, for example, contemplates preliminary steps to ensure that the assets in question are 'liable to confiscation' in some way and that the person being obliged to demonstrate their lawful origin is 'an offender' One option in such cases is to allow for a partly reversed burden of proof or a reduced burden on the state only where an offender has been convicted of the offence which generated the original proceeds. ${ }^{19}$ Some countries will use these kind of statements by the simple rule: who puts on the prima facie case to open the trial, the prosecution or the defendant? If the prosecution has the burden of proving conduct which is recognizably harmful to society, and the defendant can contest that evidence by relying on deficiencies in the government's case, by cross-examination, by presenting documents, witnesses or his or her own testimony, then the criticism is not that there is a reversal of the burden of proof but that a crime has been legislatively defined which some people do not think ought to be penalized (Shehu, 2003).

Against this background, we will now discuss a few cases from Nigeria's experience and efforts to deal with the problem of corruption and draw some lessons to illustrate the key legal issues and challenges in the recovery of proceeds of illicit enrichment.

\subsection{The Abacah Case}

General Sani Abacha, had governed Nigeria for five years from 1993 to 1998; Abacha and his cronies were alleged to have embezzled over US\$5 billion: about $\$ 2.3$ billion stolen from the treasury, and about $\$ 2$ billion were allegedly received as bribes. These monies were purportedly laundered in foreign bank accounts across the world, including Switzerland, Luxembourg, Liechtenstein, Hong Kong, UK, and USA (Ige 2002). Investigation by the UK Financial Services Authority (FSA) and the London Metropolitan Police confirmed that over $\$ 1.3$ billion of the Abachas' wealth had passed through London (Chamberlain 2002).

What is commonly referred to as the 'Abacha case' has a multidimensional reflections and implications for asset recovery as a thrust in anti-corruption and anti-money laundering. The weight of Article 53 and 54 of the UNCAC is well illustrated in the case of Sani Abacha. Indeed, the accomplishment of the Nigerian authorities in negotiations with the Swiss Government in the Matter of Sani Abacha seemed to herald the potentials and promise of asset recovery. President Obasanjo, who assumed office in May 1999, made efforts to find Abacha's stolen assets by engaging a Swiss legal firm in September 1999 to assist with a request for Mutual Legal Assistance which led to an issuance of a general freezing order.

The freezing order was however not a fait accompli. Swiss law required Nigeria to present the Swiss authorities with a final forfeiture judgment reached in the Nigerian courts before the funds could be repatriated. This would have been a daunting, if not insurmountable task, for the Nigerian Government. However, in a landmark ruling, the Swiss courts legally applied the organized crime provisions of the (then) Art 59 Swiss Criminal Code which

\footnotetext{
${ }^{17}$ See sections 28-29 of the EFCC Act for example.

${ }^{18}$ German Criminal Code Art. 73d, Singapore, Corruption Confiscation of Benefits Act, Art. 5; Art. 34a Norwegian General Civil Penal Code

${ }^{19}$ This is the framework applied by Canada, for example. See Criminal Code of Canada, R.S., c.C-34, ss.462.37 (forfeiture on balance of probabilities where offender convicted) and 462.38 (in rem forfeiture requiring proof beyond a reasonable doubt where offender is not convicted and unavailable).
} 
mandated the confiscation of 'all assets, which are subject to the power of disposal of a criminal organization'. Deeming the Abacha clan 'a criminal organization', the courts declared the assets would be confiscated except it could be shown to have a legitimate source. After a series of negotiations, which led to the selection of the World Bank as a bona fide third party for the monitoring of recovered assets, repatriation finally took place in September and November 2005 and early 2006, for a total of $\$ 505.5$ million (Monfini, 2008).

Another dimension of the Abacha case had it that after preliminary findings, the Government of Nigeria joined the family of the late head of state, Abacha, his former ministers (Ani and Dalhatu), Abubakar Bagudu, and Mecosta Company in a suit filed in the UK on 20 July 1999. In the suit, the Nigerian Government claimed that Abacha was the de facto owner of Mecosta Securities Ltd, the company that was used in the Ajaokuta debt buy-back deal. In response to the case in the High Court of Justice (Queen's Bench Division, England) Bagudu on his behalf, the Abacha family, and Mecosta Securities LTD, sought an out-of-court settlement which materialized in the signing of an agreement between the parties and the Federal Government of Nigeria. The agreement, which was negotiated by the Honourable Attorney-General and Minister of Justice of Nigeria on behalf of the Federal Government of Nigeria, was signed on 10 August 1999 with the parties. Its terms were as follows:

1) The defendants requested that the foreign accounts of the Abachas, which were frozen at the instance of the Federal Government of Nigeria, be defrozen. And that upon the release of their accounts by the government, the defendants would refund the sum of DM300 million in full and final settlement of claims made by the Government of Nigeria on the Ajaokuta Steel Complex Bill of Exchange.

2) That the US\$50 million promissory notes issued earlier by Mohammed Abacha should be rendered null and void.

3) That the settlement should be filed in the High Court of Justice (Queen's Bench Division, England) and should be adopted as the court judgment in this case; and

4) That all parties shall cooperate in discharging the judgment accordingly. Chief Bola Ige who succeeded Kanu Agabi as Attorney General and Minister of Justice later disclosed that the out of court settlement resulted in the return of over \$1 billion from various banks in Liechtenstein, Switzerland, Luxembourg, and UK (Ige, 2002).

The key legal issues and lessons from this case are many that cannot be discussed here in detail due to lack of space. Briefly stated, the steps taken by Nigeria in the Ajaokuta case briefly mentioned above, that is, the preference for criminal proceeding rather than civil actions to recover the proceeds of illicit enrichment, have tested the assumption that corruption is a predicate for money laundering. Unfortunately, the criminal law looks backwards, fixing blame and not looking forwards in a strategic sense to the need for prevention (Levi 2001; Rider 2003). Sometimes the criminal law fixes the blames on the wrong targets. Furthermore, recovery efforts have been focused too much on the corrupt leader, ignoring the intermediaries who assisted the leader in hiding his ill-gotten wealth.

The political will of both the victim and the receiving countries to take action in pursuance of the proceeds is also important because it determines what sort of action should be taken. A classic example is the negotiation between the Nigerian and Swiss governments, which led to the recovery and return of the proceeds of illicit enrichment from Abacha and his entourage to Nigeria. In a competitive financial market, financial instruments such as 'walking trust accounts', which move automatically to another jurisdiction when inquiries or Mutual Legal Assistance (MLA) requests are made in one jurisdiction, are an obstacle to recovery; this makes the collection of admissible evidence very expensive (Shehu, 2003). The tendency to misconstrue the intention of the government seeking recovery as witch-hunting is high, especially in a complex multi-ethnic society like Nigeria. The mere fact that the current regime accuses its predecessor of corruption does not mean it is not itself corrupt. Besides, it would be a travesty if the commitment of a regime to recover embezzled funds only resulted in making it easier for the successor to steal the funds.

Another lesson from this case is that governments that succeed corrupt ones may have to establish strong political legitimacy before they can galvanize the good will and support of their citizenry and the international community in the recovery of proceeds of corruption. And where a government does succeed in establishing such legitimacy, its efforts may be limited by the need not to hurt some of the economic elites who may have contributed in the political reconstruction and reconciliation process. This is perhaps why the recovery efforts of the Nigerian Government have been limited to the Abacha family. The findings of this study revealed that a good percentage of what Abacha was blamed for happened without his knowledge, even though he was ultimately responsible. In fact some commentators have described such efforts as vindictive given the failure to pursue others. 
The cost of prosecuting the Ajaokuta Steel Complex scam (one aspect of the case not discussed in detail) was estimated at US\$20 million. The point at issue therefore is that it was unnecessary for the Government of Nigeria to go through all the legal processes while the defendants had accepted making these refunds (presumably the legal pressure compelled the concessions by the Abacha family). It would appear that the government was the loser in this case since the Abachas' foreign accounts with over US\$2 billion were eventually defrozen. ${ }^{20}$

Since the Government of Nigeria embarked on its recovery of stolen funds in 1998, no single conviction has been secured. And where a conviction is not secured on a criminal charge, most countries would not be able to provide MLA. The amounts recovered so far indicate that such recovery efforts could yield more dividends when some concessions are negotiated between the parties. Overall, however, the case has sensitized the public about the possible methods that are used in illegally siphoning public funds. Most importantly, the recovery efforts illustrate how creative solutions were found to overcome teething legal challenges. Mutual legal assistance is generally slow, but civil proceedings may be costly. The success story in the recovery should be used to generate awareness of and support for asset recovery in other parts of the world.

\subsection{The Joshua Dariye Case}

Another high profile case in which stolen assets were recovered through civil forfeiture was in the matter of Joshua Chibi Dariye, who was the Governor of Plateau State in the Federal Republic of Nigeria from May 1999 through May 2007. He was alleged to have misappropriated more than USD 11.9 million during his administration $^{21}$. The funds were channeled into bank accounts in the United Kingdom and Nigeria under his name and those of his close associates. Dariye also used aliases to hide his wealth, he purchased a property in London under one "alias" and utilized business fronts to launder money. Dariye was arrested in London by the Metropolitan Police on suspicion of money laundering; a cash sum of USD \$210,000 was seized from him. After being released on bail, Dariye fled the country and was able to avoid the subsequent British international arrest warrant through his constitutional immunity as a Governor in Nigeria ${ }^{22}$.

Nonetheless, the Metropolitan Police and the Crown Prosecutorial Service, working with Nigeria's Economic and Financial Crimes Commission (EFCC) employed Kendall Freeman Solicitors to file two civil actions against Dariye to recover his London based asset. Dariye's ill-gotten wealth in the United Kingdom was confiscated through two civil actions against him by the Federal Republic of Nigeria in 2005 and 2007. The first civil action recovered a property purchased by Dariye for $£ 395,000$, while the second civil action recovered assets up to US \$5.7 million (USD \$8 million with interest) stored in Dariye's bank accounts at National Westminster and Barclays Banks in London. After losing his legal immunity in 2007, Mr. Dariye was arrested and charged with corruption and money laundering by the Nigerian Economic Financial Crimes Commission.

This is one of the cases that expose significant legal challenges to deal with. Since Dariye went into hiding during the emergency period in his state, at which time he had no immunity, it was not possible to bring him to trial. And even after he left office and was charged to court, the matter is stalled by his appeals on jurisdiction and other sundry issues from the court of Appeal to the Supreme Court. One interesting lesson is that even after a pronouncement by the Chief Justice of Nigeria that a lower court can continue with proceedings in criminal matters, such as this, even when the accused has appealed, and after adopting a new 'Practice Directions' in respect of such matters, this matter has prolonged. There are few former Governors that have also been investigated and charged to court after leaving office, but no single one has been convicted apart from Mr. Lucky Igbenidion (former Governor of Edo State) who pleaded guilty in a plea bargain (discussed subsequently in this paper).

As evidenced in the Dariye case, a vital aspect of asset recovery is international cooperation between countries. Articles 43,44 , and 46 of the UNCAC respectively make provisions for international cooperation, extradition and Mutual Legal Assistance. States are to ensure the widest measure of Mutual Legal Assistance (MLA) in investigations, prosecutions, judicial proceedings and asset confiscation and recovery in relation to corruption offences, particularly when taking evidence from persons, identifying and tracing the proceeds of crime or providing documents and records. Although MLA does not cover civil actions, as shown in the Dariye case, utilizing informal cooperation and assistance can be just as effective in civil matters. These cases were won

\footnotetext{
${ }^{20}$ For further details, See the News Magazine, 10 April 2001; Vanguard, 15 November 2001 and the Guardian, 18 November 2001, all published in Lagos.

${ }^{21}$ This case is still under trial as at the time of this writing and therefore care had to be taken with regard to subjudice.

${ }^{22}$ A 'State of Emergency' was declared in his state for six months in 2006, hence he went into hiding only to resurface and assumed office after the expiration of the 'State of Emergency' to conclude his tenure as Governor in 2007.
} 
based on the effective asset forfeiture and asset recovery provisions, including civil forfeiture that existed the UK. The lack of comprehensive civil forfeiture provisions in Nigeria impedes the recovery of assets in the country.

\section{The Challenges of Asset Recovery in Nigeria}

The existing legal and institutional framework for asset recovery in Nigeria is still evolving ${ }^{23}$. Although the country has made provision for confiscation pursuant to a criminal conviction in the MLPA 2011 and the EFCC Act, based on the outcome of cases that have been handled by the EFCC, it can be argued that the institution has been effective in respect of fraud cases involving ordinary citizens but less so in respect of cases involving Politically Exposed Persons (PEPs). In other words, prosecutions and convictions are fewer in matters involving PEPs and many of these cases are being delayed while others have been struck out by the courts. One of such cases struck out by the court is the 'famous Halliburton bribery case' in which the EFCC filed a lawsuit against officials accused of receiving bribes from officials of Halliburton, an American-based energy company. Even though the US courts had convicted top officials of Halliburton for bribing some Nigerian officials with sums amounting to \$200 million for the purpose of obtaining contracts worth billions of dollars from the Nigerian government; in contrast to the decision in the United States, a Federal High Court in Abuja, struck out the case, accusing the EFCC prosecutors of failure to diligently prosecute the case. Similarly, a High Court of the Federal Capital Territory, Abuja, struck out the fraud charges filed by the EFCC against Mr. Ndidi Elumelu, the former Chairperson of the House of Representatives Committee on Power. The lawsuit which accused the lawmaker and his co-accused of stealing some N5.2 billion budgeted for rural electrification was dismissed by the judge who ruled that the accused had no case to answer ${ }^{24}$.

Also in a dramatic decision which has been described as 'politically motivated', the federal government of Nigeria suddenly withdrew charges against Mohammed Abacha, the son of the late Head of State, General Abacha (case discussed above). Transparency International (TI) issued a statement criticizing the government and describing such action as inconsistent with the government's commitment to fight corruption, but the government replied TI justifying that Nigeria was doing its outmost best in fighting corruption under the Goodluck Jonathan administration.

There are many more cases like those cited above and it has become apparent that where PEPs and powerful public officials are concerned, the law enforcement agencies are still struggling to achieve conviction. The Human Rights Watch stated that the EFCC has had significant success in tackling private sector corruption, but from a human rights standpoint, what is key, is public sector corruption because endemic government corruption in Nigeria has undermined the basic rights of millions of Nigerians ${ }^{25}$ The Human Rights Watch also observed that "proven criminality" was "no bar" to the highest echelons of politics in Nigeria. In spite of this criticism, the group acknowledged that the EFCC was the most promising agency to confront corruption in the country and had recovered some $\$ 11 \mathrm{bn}(£ 6.7 \mathrm{bn}$ ) through its efforts in the eight years since it was formed. These observations call for a new approach and strategy by the enforcement agencies because until the legal and institutional framework in which they operate is strengthened and they are fully empowered to conduct investigations and prosecutions without interference, they will continue to be ineffective where it matters - i.e. tackling high level corruption.

Recovering the proceeds of crime is premised on evidence; that is, the existence of assets. Thus, in order to conduct a successful recovery of criminal proceeds, assets must be followed not only to their final hiding place, but causality must be established between the asset and the criminal activity. This process is complex, technical and time consuming as such, it poses particular challenges for developing countries like Nigeria that have a cash based society and limited investigative capacity. Stolen assets are often layered through different accounts and corporate vehicles; therefore, identifying and tracing illicit assets successfully require expertise, resources and cooperation between multiple intelligence and law enforcement agencies, as well as prosecutors. It is thus, crucial for the Financial Intelligence Unit (FIU), law enforcement agencies and prosecutors to cooperate and work together to build an iron clad case each and every time.

\footnotetext{
${ }^{23}$ Nigeria was rated Partially Compliant (PC) in its mutual evaluation report in 2008 on the FATF Recommendation 3 dealing with confiscation and provisional measures. The reasons advanced for this low rating included the lack of definition of important concepts such as freezing, seizure, forfeiture and confiscation as well as inconsistency in the laws relating to freezing of assets ; Insufficient legal protection for bona fide third parties ; and Absence of rules to manage and dispose of confiscated properties.

${ }^{24}$ Various reasons have been speculated to be the reasons for the inconclusive or unsuccessful prosecution of cases involving high level political persons, including the lack of diligent prosecution by the respective agencies; "political protection" for most of the offenders who are seen as strong party stalwarts, and often allegations of compromise by judges.

${ }^{25}$ Eric Guttschuss Human Rights Watch
} 
The EFCC Act (2004) makes the EFCC the coordinating agency for the enforcement of the provisions of various Acts $^{26}$ related to economic crime. This coordinating role needs to be undertaken effectively in order to bring perpetrators to book and recover the proceeds of crime. Often than not, different law enforcement agencies want to protect their "tuft" so to speak. These "tuft fights" only impede effective prosecutions and confiscations. Meanwhile, the Revised FATF Recommendation 2 now requires countries to coordinate domestically to fight money laundering and terrorist financing. In its Mutual Evaluation Report (Nigeria MER, 2008), Nigeria was rated partially compliant on the FATF Recommendation 31, meaning that the level of cooperation and coordination among key agencies was poor. The MER noted that while there was a framework in place for cooperation, the Committee does not meet regularly; The Financial Institutions (Fis) and other Financial Institutions (OFIs) committees seemed to be working well, but the law enforcement agencies (LEAs) lacked considerable cooperation and thus, both lacked the synergy required to combat ML and TF effectively. Also, that Nigeria had not institutionalized the inter-agency committee to enable it meet more frequently to develop policies and issue guidelines as the need arises. And finally, that AML/FT intelligence is not widely shared across relevant law enforcement agencies. This has been a major challenge in Nigeria's efforts to recover the proceeds of crime as illustrated in some of the cases discussed below.

In addition to strengthening the institutional framework for asset recovery, the need to strengthen the legal frame work to combat economic crimes cannot be overstated. A legal framework which hinges on taking the profit out of crime by recovering crime proceeds has the indispensable ingredient for an effective sanction regime. Although, most countries, including Nigeria, have put in place a legal frame work for confiscation of criminal proceeds pursuant to criminal proceedings, the avenues for recovering illicit proceeds through the civil courts have, however, not been fully established within Nigeria's legal framework.

\subsection{The Ibori Case}

The importance of enacting a Non-Conviction Based (NCB) asset forfeiture law in Nigeria is indicated in the Ibori case $^{27}$. Briefly stated, James Ibori, former governor of Delta State in Nigeria, pleaded guilty to money laundering offences at the Southwark Crown Court in the United Kingdom. The ex-governor admitted to fraud in excess of $£ 50$ million and was convicted. After the Judgements in the British courts, the Economic and Financial Crimes Commission (EFCC), reiterated their intention to prosecute Ibori at an appropriate time, noting that the offences for which the governor pleaded guilty was only a minute part of the list of offences he committed during his tenure as governor. Most of the criminal charges against Ibori are still before Courts in Nigeria and there are no plans to vacate them. Unfortunately, the EFCC cannot proceed against Ibori until he finishes serving his jail term and there is nothing to say that the Governor would return to Nigeria after serving his jail term. Given that it is impossible to try him in absentia, a number of events might occur during the waiting period. Importantly, his associates which include highly placed politicians and public servants may assist him to dissipate assets which are acknowledged to be located all over the world. If Nigeria had NCB laws ${ }^{28}$, it would have aided the recovery of a considerable number of illicit assets acquired by the former Governor. NCB would have been the ideal way to recover Ibori's illicitly obtained assets. This case is a perfect example of how the NCB asset forfeiture laws could be used by prosecuting authorities as a vital tool to deprive kleptocrats of ill-gotten wealth. Nigeria is however yet to enact a comprehensive law on non- conviction based confiscation. The purpose of NCB is to hit the criminal where it hurts most. It is important for criminals to recognize that illicit assets will always be followed and recovered, even in the absence of the perpetrators and that the chances of returning to a life of opulence to spend the rest of the loot at a later date are slim. Thus, it is important that the Forfeiture Bill which has been pending in the National Assembly is passed without further delay ${ }^{29}$.

\footnotetext{
${ }^{26}$ (a) the Money Laundering Act 2011; (b) the Advance Fee Fraud and Other Related Offences Act 1995 ; (c) the Failed Banks (Recovery of Debt and Financial Mal-practices in Banks) Act, as amended;(d) the Banks and Other Financial Institutions Act 1991, as amended:(e) Miscellaneous Offences Act; and $(j)$ and other laws or regulations relating to economic and financial crimes, including the Criminal Code and Penal Code.

${ }^{27}$ For lack of space, we will not go into the details of over 172 charges that the EFCC initially put against Ibori and his subsequent acquittal by the trial court and the ruling of the supreme court with regard to the issue of jurisdiction in that matter as they are separate legal issues altogether. Thus, I concentrate on the substance that brings out the issue of using civil proceedings to recover proceeds of illicit enrichment.

${ }^{28}$ Even though NCB has been criticized that it undermines the effectiveness of criminal law and the confidence in the law enforcement and it should not be an alternative to prosecution (Greenburg \& Samuel, 2009).

${ }^{29}$ Some of the disadvantages of the civil route in the recovery of criminal proceeds had earlier been discussed in this paper and need not restated here.
} 


\section{Mutual Legal Assistance}

Mutual Legal Assistance (MLA) mechanisms enable countries to acquire crucial evidence or other forms of legal assistance to enable them prosecute or recover illicitly acquired asset. Countries have developed mechanisms for requesting and obtaining evidence for criminal investigations and prosecutions. The scope of assistance should include production, search and seizure of information, documents or evidence (including financial records) from financial institutions or other persons, the taking of witness statements ${ }^{30}$ and the service of documents, states may cooperate informally through respective agencies, including the law enforcement and the judiciary. In the past, the system of letters rogatory were frequently employed to request assistance. The FATF Recommendation 37 enjoins countries to rapidly, constructively and effectively provide the widest possible range of mutual legal assistance in relation to money laundering, associated predicate offences and terrorist financing investigations, prosecutions, and related proceedings. Countries should have an adequate legal basis for providing assistance and, where appropriate, should have in place treaties, arrangements or other mechanisms to enhance cooperation. It is now far more common for states to make mutual legal assistance requests directly to the designated "Central Authorities". Such requests may still be made on the basis of reciprocity, but may also be made pursuant to bilateral and multilateral treaties that obligate countries to provide assistance.

Nigeria depends on a wide-range of bilateral and multilateral treaties and agreements to execute international cooperation requests on criminal matters (Nigeria, MER 2008). It has entered into such agreements with Commonwealth countries, ECOWAS Member States, Russia, United States and Iran. However, there is no specific requirement for MLA to be executed within a specified time. There is also no process in place for monitoring Nigeria's performance or average time required for responding to MLA. The MER further stated that the execution of MLA requests requires reference to various bilateral and multilateral agreements and the negotiation of agreements as the need arises and this may inhibit prompt response to MLA requests. Criminals will always want to hide stolen monies in jurisdictions with inadequate countermeasures to combat economic crime, such as where government will find it difficult or impossible to repatriate such monies. Although countries are able to provide a broad range of mutual legal assistance to other countries even in the absence of a treaty, a comprehensive MLA law will ensure timely and effective collaboration with third countries and prevent dissipation of funds. Thus, there is a need for Nigeria to enact a comprehensive Mutual legal Assistance Law.

Legislation which provides for the tracing, freezing, seizing and forfeiture of funds or other assets derived from corruption is a powerful weapon in anti-corruption strategies because it targets the essential motive of corruption- economic gain. As noted above, legislative frameworks often combine elements of criminal law, criminal procedure and civil or administrative law, which create options flexible enough to deal with a range of corruption scenarios. If there is sufficient evidence to prove that corruption has occurred and that particular assets are derived from it, for example, it may be possible to target the proceeds even where it is not possible to prosecute offenders. Some national frameworks also allow for proceeds to be targeted either by victims or the state in civil proceedings, which may carry a lower burden of proof than those required to apply criminal prosecutions and punishments. ${ }^{31}$

To be acted upon, a MLA request must emanate from the court exercising criminal jurisdiction in such matters, or the appropriate department of government - in Nigeria, the Federal Ministry of Justice. The request must also contain a short statement of the offence that has been committed or under which the accused is being tried, or on which investigation is being carried out.

The greatest advantage of MLA, especially in regard to the Abachas' case is that it is relatively cost effective as the UK Government usually bears the cost of execution in its jurisdiction. Furthermore, it has the potential of overcoming the obstacles related to bank secrecy. In other words, it represents an obligation that has to be implemented in accordance with domestic law. MLA has the promise of being effective in securing admissible

\footnotetext{
${ }^{30}$ For details on the standard requirements on mutual legal assistance, see the FAFT Recommendation 37

${ }^{31}$ In the United States, some statutes allow for confiscation on a civil basis, which entails a lower burden of proof, effectively placing an onus on the owner to establish legitimacy once the State has established probable cause or a probability that the property is the proceeds of crime (see 31 USC §5316), but this has also been strongly criticized as violating rights of property and the presumption of innocence. Italy allows for special administrative procedures for forfeiture and confiscation of assets independently of criminal conviction. There, property owned by any person suspected of participating in Mafia-type associations can be confiscated if it cannot be accounted for from legitimate sources or if it can be established by evidence that it derives from illicit sources, if the owner cannot establish legitimate origin (see Law \#575 of 31 May 1965 , article 2ter). The EFCC Act of Nigeria addresses this aspect of pecuniary resources in s.19(5) for the accused to prove that it does not represent proceeds of crime.
} 
evidence necessary in criminal proceedings. It is assumed to be more efficient because it passes through a central authority, while letters regatory and diplomatic correspondence pass through the court or through embassies. Further, MLA has the additional advantage in that there is no cost for employing attorneys to pursue the kind of assistance requested (Graham 2002: 171). In short, MLA has a stronger capacity than usually recognized because most international instruments, such as the UN Conventions, provide that states should give the widest form of MLA in criminal matters.

Like any legal instrument, however, MLA has its own weaknesses. One of its disadvantages is that a recognized procedure for the return of confiscated funds to the 'victimized' state remains to be established. Although in the US there are guidelines for the sharing of forfeited asset; in Nigeria, which may be the same with the UK, the position is that confiscated assets are the property of the government - it goes into the consolidated revenue. Thus, there is the need for especial concessions to be given to developing countries especially on moral grounds for the return of stolen funds to its country of origin. ${ }^{32}$ The idea of an international trust fund to manage and monitor the return of recovered funds is gaining ground, but the mechanism for such an arrangement remains unclear.

Another major disadvantage of MLA is that there are many questions surrounding the procedure for the use of evidence obtained by the requesting state. Would it be possible to use evidence obtained through MLA for parallel and/or subsequent proceedings should the requesting state prefer doing so? In other words, can such evidence be used for civil proceedings? Obviously, it is not possible to stop the requesting state from doing so although the indigenous courts could always exercise discretion as to whether evidence obtained in another jurisdiction should be accepted or not.

Mutual legal assistance has been criticized for being ineffective in money laundering investigations because it is seldom able to provide rapidly the evidence or information required for the immediate freezing of suspects' assets. A bilateral approach generally has the tendency of producing piecemeal results and relying too much on goodwill (Shehu, 2003). Comparatively, criminal proceedings are much longer than civil claims. Criminal courts have no jurisdiction to investigate and prosecute offences committed abroad in most countries (including Nigeria). Civil courts, however, have powers to hear cases involving offences that took place in another jurisdiction. Whereas in criminal proceedings, the burden of proof is beyond reasonable doubt; in civil proceedings, it rests merely on the balance of probabilities. There is no evidence, however, to suggest that the presumption of innocence has been a hindrance to prosecution and forfeiture. In the US, the presumption of innocence is evidentiary rather than substantive. Therefore, developing countries should rethink the criminal proceedings and consider the alternative route of making civil claims since in most cases, as with Nigeria, the objective is to recover the funds. Shaming the offender will automatically result from such recovery when publicized (Shehu, 2003).

\section{Plea bargain}

Plea bargain has come to the fore in legal and criminological discourse on recovery of assets. The Black's Law Dictionary defines a plea bargain as the process whereby the accused and the prosecutor in a criminal case work out a mutually satisfactory disposition of the case subject to court approval. It usually involves the defendant's pleading guilty to a lesser offense or to only one or some of the counts of a multi-count indictment in return for a lighter sentence than that possible for the graver charge. So an advantage of plea bargaining is that the prosecution secures a faster conviction, though the offender ends up getting a milder punishment than what should have obtained normally.

The UNCAC in Article 37(1) states that each State Party shall take appropriate measures to encourage persons who participate or who have participated in the commission of an offence established in accordance with this Convention to supply information useful to competent authorities for investigative and evidentiary purposes and to provide factual, specific help to competent authorities that may contribute to depriving offenders of the proceeds of crime and to recovering such proceeds. Article 37(2) provides that each State Party shall consider providing for the possibility, in appropriate cases, of mitigating punishment of an accused person who provides substantial cooperation in the investigation or prosecution of an offence established in accordance with this Convention. Article 37 (3) states that each State Party shall consider providing for the possibility, in accordance with fundamental principles of its domestic law, of granting immunity from prosecution to a person who provides substantial cooperation in the investigation or prosecution of an offence established in accordance with this Convention. These provisions presumably, contemplate some form of plea bargain.

\footnotetext{
${ }^{32}$ See Chapter V Arts. 51-54 of the UNCAC dealing with the recovery and return of proceeds of illicit enrichment.
} 
In Nigeria, the plea bargaining has been employed in some high profile cases prosecuted by the Economic and Financial Crimes Commission. Let us briefly mention a few cases in which the plea bargaining was applied with a view to exploring the strength and weaknesses of the process, as well as the challenges in its implementation in Nigeria. The first case in point is that of Tafa Balogun V. The Federal Republic of Nigeria (FRN), the former Inspector General of Police (IGP). Tafa Balogun was arraigned at the Federal High Court, Abuja, on charges involving about N13 billion obtained through money laundering and theft .The Economic and Financial Crimes Commission (EFCC), in a suit No. FHC/ABJ/CR/14/2005, brought 70 charges against Tafa Balogun covering the period from 2002 to 2004 . He entered a plea bargain with the court in exchange for returning much of the property and money. The charges were collapsed into eight counts and the former IGP was given a six-month jail term for each of the eight counts, to run concurrently, as well as a fine of $\mathrm{N} 500,000$ for each count ${ }^{33}$. It is important to note that the EFCC stated that they did not have records of the exact properties recovered from Balogun. ${ }^{34}$

Similarly, a second case involved Dieprieye Solomon Peter Alamieseigha, former Governor of Bayelsa State, who was convicted of stealing public assets worth over $\$ 100$ million $^{35}$. He pleaded guilty to six charges and was sentenced to two years imprisonment on each charge, to run concurrently and an order of asset forfeiture for those assets that were traced ${ }^{36}$. Another case example involved Lucky Igbinedion, a former Governor of Edo state, whose 191 counts charge was reduced to one count charge of corruption and after plea bargaining, he was sentenced to a mere six months imprisonment with option of $\mathrm{N} 3.5 \mathrm{~m}$ fine.

Yet, in another high profile case involving Cecilia Ibru, the former Chief Executive Officer and Managing Director of Oceanic Bank Plc. Who was arraigned before the court by the EFCC on a 25-count charge involving corruption while in office. After negotiation with the EFCC, the charges against her were reduced to three. Cecilia Ibru agreed to plead guilty to the reduced charges of mismanagement and abuse of office. As a result of the plea bargain, Mrs. Ibru was given three sentences of six months imprisonment on each of the three counts, to run concurrently and ordered to forfeit N 191 billion worth of properties and assets to the government. The accused spent a substantial number of her sentences at a private hospital ${ }^{37}$.

All these generated a lot of outcry and criticisms rightfully or wrongfully from the public, but the most disturbing decision that generated more controversy was that reached in the case of John Yusuf, who embezzled N27.2 billion from the pension fund of retired police officers. He was sentenced to two years imprisonment with the alternative of a fine of N750, 000.00. He naturally paid the fine. Because of many legal issues this court decision generated, the judge was suspended for one year on account of abusing the legal process even though there was no where he was faulted of misapplying the law.

Honourable Justice Dahiru Musdapher, former Chief Justice of Nigeria (CJN), in his opening remarks at the All Nigeria Judges' Conference on 21 November 2011 in Abuja, Nigeria, dismissed plea bargain as "a novel concept of dubious origin," and insisted that "it was invented to provide soft landing to high profile criminals who loot the treasury entrusted to them. He remarked that "plea bargain was never part of our legal system until it was surreptitiously smuggled into our statutory laws with the creation of the EFCC". Proponents of plea bargain contend that there are various laws which support the use of plea bargain in the Nigerian legal system, namely; Section 180 of the Criminal Procedure Act, Section 13(2) EFCC Act, 2004, and Section 76 of the Criminal Justice Law, Laws of Lagos State, 2007. The main contention however, relates to the manner of invoking and applying plea bargaining in Nigeria.

Undoubtedly, many of the sentences imposed under the plea bargain process are generally perceived as being merely a "slap on the wrist" without the necessary deterrent effect. The decision reached by the courts in the above cases tend to support the former CJN's statement that plea bargain was invented to provide soft landing to high profile criminals who loot the treasury entrusted to them. Plea bargain has certain advantages, though, since it can aid the disposal of criminal cases and the management of court dockets, as well as minimise the cost of prosecution. Nevertheless, what is important to note is that these cases highlight the need for transparent and

\footnotetext{
${ }^{33}$ Judgment dated 22 November 2005 was not reported as only cases decided at the Court of Appeal and Supreme Court are reported in the Nigeria Law Report.

${ }^{34}$ Uncertainty over Tafa Balogun's loot". The News Planetario. May 24, 2009

${ }^{35}$ See Federal Republic of Nigeria v. Diepreye Solomon Peter Alamieseigha \& 6 Othrs (2006), 16 NWLR Pt. 1004.

${ }^{36}$ In 2013, Chief Alamieseigha was granted state pardon, which was criticized by some members of the public.

${ }^{37}$ In April 2014, Mrs Ibru filed a suit in court, seeking to revise the terms of agreement in the plea bargain she had earlier entered into with the EFCC.
} 
consistent application of plea bargain process.

From the reactions to these and perhaps other cases in which the plea bargaining was applied, a number of key legal issues were raised. First, is the question as to whether it is part of the Nigerian legal system to apply plea bargain. Without going into the legal controversies to answer that question, the simple answer would be that even if it is not part of the legal system, no one has also pointed out where it is entirely illegal. Section 30 of the EFCC Act has provided for forfeiture of criminal proceeds as a form of punishment. It states that "Where a person is convicted of an offence under this Act, the Commission or any authorized officer shall apply to the court for order of confiscation and forfeiture of the convicted person's Properties acquired or obtained as a result of the crime, subject to an interim order under this Act".

The point in issue is that the EFCC may apply any process of law to achieve this, and one of which is the plea bargaining. Although it has the benefit of accelerating the trial process and increasing the number of convictions if the goal is to secure conviction per se, it also has some weaknesses too significant to ignore, especially in the Nigerian context. Plea bargaining, as it is copied from the American application would work in countries like the USA where there is complete record of assets, including the financial profile of each individual. In Nigeria, it is difficult to ascertain the completeness of records of assets and financial profile of everybody due to poor records keeping and the use of proxies to acquire properties and maintain businesses. Thus, if beneficial ownership of a property is not fully established, applying plea bargain to recover the proceeds of a criminal offence may only succeed partially in denying the offender the benefit of criminal proceeds.

Based on the above observations therefore, it is crucial to establish clear and comprehensive rules of court on the issue of plea bargain and note that punishment, notwithstanding, the recovery of asset, should be dissuasive.

\section{Asset Management}

Asset management is an important aspect of recovering the proceeds of crime because it ensures that assets, once recovered do not get stolen again by yet another group of "kleptocrats". Asset recovery process has two levels: the first level is action to identify, trace, freeze, and confiscation; and second level is how to manage the proceeds according to acceptable laid down procedure and the law. It is thus important to establish a legal framework for managing and utilizing the funds for development purposes.The provisions for managing recovered assets from economic crimes in Nigeria are weak. Bolstering prosecution, securing conviction of perpetrators of these crimes and recovering the stolen assets are all important; however, to pursue the fight against money laundering to its logical conclusion, management of confiscated and recovered assets must be safeguarded. What is more, it will ensure that the pains-staking efforts of law enforcement agents and civil society organizations are not wasted, but rather rewarded through handing down effective punishment to perpetrators of these crimes and utilizing recovered funds for its rightful purpose.

One of the main thrusts of the UNCAC is prevention. Parallel to the recovery effort, it is essential to strengthen national mechanisms designed to prevent the diversion of funds through corrupt practices. This would not only help to protect the country and its people from being victimised by future generations of corrupt leaders or high-level public officials but would also contribute to the credibility of the recovery effort, giving additional legitimacy to the request for international judicial assistance. Such measures should include the strengthening of official anti-corruption bodies in their role to prevent and control corruption at the national level; the development and implementation of a comprehensive national integrity strategy; and more specifically, the design of mechanisms to monitor expenditure, particularly on development projects involving the recipients, as well as civil society at large (Shehu, 2003).

One of the ethnical reforms often recommended is the declaration of assets by public office-holders, before and after vacating office. In Nigeria, however, the practice of declaring assets in secrecy to the ethics or Code of Conduct Bureau has been criticized as being unhelpful to the fight against corruption. When the public is not aware of what a public office-holder declares as legitimate assets before assuming office, how can they verify or report irregularities or false disclosure of wealth? It is therefore strongly recommended that assets declaration by public office-holders be made open to the public, without the encumbrance of having to seek a court injunction to see $\mathrm{it}^{38}$.

On the other hand, open declaration may not serve useful purposes if the public is not aware of its responsibility to report corruption and money laundering cases. Public education, enlightenment, and massive publicity about

\footnotetext{
${ }^{38}$ Perhaps with the passage of the Freedom of Information Act, accessibility to official assets records may be easier, but there is no evidence to show.
} 
the work of anti-corruption agencies are therefore crucial. The media should be in the vanguard of raising awareness about these ills in society. Criticism and reports of malfeasance must be constructive, and professionally objective, something it has been difficult to achieve in Nigeria and some countries considering the pattern of media ownership. A truly free press should be protected from legal or other harassment and should develop and abide by ethical standards of conduct.

Effective partnership with the private sector would also be helpful not only in reducing corruption but also in efforts to recover the proceeds of crime. The private sector must share a common view of the problem and commit to enforce ethical standards and measures to prevent the laundering of the proceeds of crime in their system.

These measures could be financed through a 'governance premium', that is a 1-3\% portion of the recovered funds, as well as every donor contribution received by Nigeria. ${ }^{39}$ However, realising that a merely government-driven initiative might not be perceived as credible by the general public, the ICPC and EFCC should be responsible for the planning, implementation and monitoring of an integrated national integrity strategy and anti-corruption action plan. Such a governance premium would encourage the donor community to allocate the necessary funds to strengthen the recipient countries' national integrity systems.

In some jurisdictions, including the USA, certain per centage of the recovered funds is allocated to law enforcement. This author would advocate this for Nigeria, regardless of the constitutional provision that recovered funds go into the consolidated revenue fund. After all, the constitution is meant for the people and not vice versa, and so it can be amended if the wisdom in doing so is over riding.

\section{Conclusion}

In conclusion, this paper has contributed to knowledge by exposing the key legal issues and challenges that countries face in the recovery of proceeds of crime. For a country to adopt any of the approaches discussed here to recovery proceeds, therefore, it is crucial that certain fundamental questions should be addressed, namely: (1) a country must decide from the outset what it intends to do with the offender - i.e. what should be its objectives in any process - to convict the culprit and recover the asset or just to recover that assets or both. In the plea bargain cases above, it seems the objective was to achieve conviction (through a short cut), but whether that is satisfactory remains contentious; (2) the target involved in any process should assist in determining the approach to take. Securing conviction in cases involving PEPs has proved difficult in Nigeria, hence the asset recovery approach must take into certain difficulties associated with establishing the true value of the assets, their origins, ownership and locations i.e. proportionality of the estimated assets with the alleged crime; (3) what are the legal problems within and outside the country seeking to recover the assets, including issues of burden of proof and fundamental rights and how can they be surmounted? (4) how the process can be managed, especially when the accused is dead; how do you generate cooperation from other jurisdictions, especially when powerful multinationals are involved?; and most importantly, it should be clear that the cost of recovery justifies commencing the process (Ribadu, 2008: 29).

Confiscating and recovering the criminal assets and freezing of terrorist assets are indispensable aspects of anti-money laundering and terrorist financing efforts. It is important to send a signal to potential offenders that if discovered and convicted, they will not only be subjected to immediate custodial sentences of a substantial character, but will also lose tainted property. Consequently, strengthening prosecutorial and judicial capacity to achieving conviction and record successful asset recovery constitutes an area of priority.

Where the bureaucracy is stronger than the institutions for maintaining accountability, equity and justice, such a situation would facilitate what might be described as a 'kleptocracy'. In Nigeria, for example, political offices are seen as avenues and opportunities for amassing wealth so as to 'capture' and retain power. The bureaucracy is actually the instrument that is used, knowingly or otherwise, to achieve this goa ${ }^{40}$. Hence, the anti-corruption effort must include a reform of the bureacracy.

\section{References}

Chamberlain, K. (2002). Recovering the Proceeds of Corruption. Journal of Money Laundering Control, 6(2),

\footnotetext{
${ }^{39}$ The recipient of this premium should be the ICPC and the EFCC as the institutions with the mandate to carry out the tasks described above. However, when such provision was included in the amended EFCC Act, it was expunged because, as it was argued, that contravenes the Constitution.

${ }^{40}$ See reports of the various probe panels and committees of enquiry that have been set up by successive governments: Cabinet Office and Federal Ministry of Justice, Abuja, Nigeria.
} 
159-165. http://dx.doi.org/10.1108/13685200310809518

Economic and Financial Crimes Commission. (EFCC, 2004). Act.

FATF. (2012). International Standards on Combating Money Laundering and the Financing of Terrorism and Proliferation - The FATF Recommendations. Paris, France.

GIABA. (2007-2013). Mutual Evaluation Reports on Countries in West Africa. Retrieved from http://www.giaba.org/mutualevalautions

GIABA. (2010). Corruption- Money Laundering Nexus: An Analysis of Risks and Control measures in West Africa. Dakar, Senegal.

Global Financial Integrity (GFI). (2009). The Absorption of Illicit Financial Flows from Developing Countries: 2002-2006; Illicit Financial Flows from Developing Countries (With Update from Asia) - 2000-2009; and Illicit Financial Flows from Africa: Hidden resource for Development.

Greenburg et al. (Eds.). (2009a). Stolen Asset Recovery - A Good Practices Guide for Non-Conviction Based Asset Forfeiture, World Bank StAR Initiative, washington DC, USA.

Greenburg et al. (Eds.). (2009b). Stolen Asset Recovery - Politically Exposed Persons: A Policy Paper on Strenghtening Preventive Measures, World bank StAR Initiative, Washington, DC.

Ige, B. (2002). Abacha and the Bankers: Cracking the Conspiracy. Forum on Crime and Society, 2(1).

Levi, M. (2001). Financial Measures against Illegal Drugs: An Overview. London: Police Foundation.

Monfrini, E. (2008). The Abacha Case. In M. Pieth (Ed.), Recovering Stolen Assets (pp. 41-59). Peter Leng, Benn, Switzerland.

Nigeria. (2008). Mutual Evaluation Report. Retrieved from http://www.giaba.org.mutualevaluations

Nigeria. (2011). Money Laundering Prohibition Act (MLPA).

Ribadu, N. (2008). The Challenges and Opportunities of Asset Recovery in a Developing Country. In M. Pieth (Ed.), Recovering Stolen Assets (pp. 29-35). Peter Lang, AG, Bern, Switzerland.

Rider, B. A. K. (2003). The Financial War on Terror- Bluff or Bluster? Paul Hastings Visiting Professorship Lecture. Asian Institute of International Financial Law, The University of Hong Kong.

Shehu, A. Y. (2003a). Corruption and Money Laundering: A Comparative Study of Nigeria and Hong Kong. A Ph.D. Dissertation submitted to the University of Hong Kong.

Shehu, A. Y. (2003b). Combating Corruption and Money Laundering: An Appraisal of Mutual Legal Assistance Mechanisms. Paper Presented at the $11^{\text {th }}$ International Anti-corruption Conference (IACC), Seoul, Korea, 25-28 May 2003.

Shehu, A. Y. (2006, April-June). Recovering the Proceeds of Corruption: The challenges for developing Countries. Nigerian Journal of Economic and Financial Crimes, 1, 27.

United Nations Convention against Corruption. (2003).

United Nations Convention against Transnational organized Crime. (2000).

World Bank. (2009). Stolen Asset recovery - Management of Returned Assets: Policy

Considerations. StAR Initiative, Washington, DC. USA.

\section{Copyrights}

Copyright for this article is retained by the author(s), with first publication rights granted to the journal.

This is an open-access article distributed under the terms and conditions of the Creative Commons Attribution license (http://creativecommons.org/licenses/by/3.0/). 